\title{
Plant phenology and life span influence soil pool dynamics: Bromus tectorum invasion of perennial $\mathrm{C}_{3}-\mathrm{C}_{4}$ grass communities
}

\author{
Elizabeth Carol Adair • Ingrid C. Burke
}

Received: 7 January 2010 / Accepted: 22 April 2010/Published online: 14 May 2010

(C) The Author(s) 2010. This article is published with open access at Springerlink.com

\begin{abstract}
In water-limited ecosystems, small rainfall events can have dramatic impacts on microbial activity and soil nutrient pools. Plant community phenology and life span also affect soil resources by determining the timing and quantity of plant nutrient uptake, storage, and release. Using the replacement of $\mathrm{C}_{3}-\mathrm{C}_{4}$ perennial grasses by the invasive annual grass Bromus tectorum as a case study, we investigated the influence of phenology and life span on pulse responses and sizes of soil carbon (C) and nitrogen (N) pools. We hypothesized that available and microbial $\mathrm{C}$ and $\mathrm{N}$ would respond to small rainfall
\end{abstract}

Responsible Editor: Gerlinde De Deyn.

\section{E. Carol Adair}

Department of Forest, Rangeland, and Watershed Stewardship, and Graduate Degree Program in Ecology,

Colorado State University,

Fort Collins, CO 80523, USA

I. C. Burke

Haub School and Ruckelshaus Institute of Environment and Natural Resources (ENR), University of Wyoming, Dept. 3971, 1000 E. University Ave.,

Laramie, WY 82071, USA

E. Carol Adair $(\bowtie)$

National Center for Ecological Analysis and Synthesis, University of California Santa Barbara,

735 State Street, Suite 300,

Santa Barbara, CA 93101-5504, USA

e-mail: adair@nceas.ucsb.edu events and that $B$. tectorum invasion would increase soil $\mathrm{C}$ and $\mathrm{N}$ pools by reducing inter-annual plant $\mathrm{C}$ and $\mathrm{N}$ storage and alter seasonal pool dynamics by changing the timing of plant uptake and litter inputs. We tested our hypotheses by simulating small rainfall events in $B$. tectorum and perennial grass communities three times during the growing season. Microbial pools responded strongly to soil moisture and simulated rainfall events, but labile $\mathrm{C}$ and $\mathrm{N}$ pools were affected weakly or not at all. All pools were larger beneath $B$. tectorum than perennial grasses. Soil $\mathrm{C}$ and $\mathrm{N}$ pools increased after senescence in both communities. Our results suggest that transforming a perennial into a $B$. tectorum dominated community increases the overall size of soil $\mathrm{C}$ and $\mathrm{N}$ pools by decreasing plant $\mathrm{C}$ and $\mathrm{N}$ storage and changes seasonal pool dynamics by altering dominant plant phenology. Our results indicate strong roles for water, life span and phenology in controlling soil $\mathrm{C}$ and $\mathrm{N}$ pools and begin to elucidate the biogeochemical effects of altering plant community phenology and life span.

Keywords Inorganic nitrogen · Dissolved organic carbon and nitrogen $\cdot$ Microbial biomass .

Pulse dynamics

\section{Introduction}

In semi-arid ecosystems, soil carbon (C) and nitrogen (N) pools and fluxes fluctuate through time with 
rainfall events (Noy-Meir 1973, Schwinning and Sala 2004, Collins et al. 2008) and seasonal changes in plant and microbial activity (Jackson et al. 1988, Wedin and Tilman 1990, James et al. 2006). Rainfall induced "pulses" of resource availability stem from the reduction or alleviation of water limitation of plant and microbial processes, which increases $\mathrm{C}$ and $\mathrm{N}$ mineralization, mineral $\mathrm{N}$ pools, and nutrient supply to plant roots (Nye and Tinker 1977, Cui and Caldwell 1997, Austin et al. 2004, Huxman et al. 2004, Ford et al. 2007). Rainfall events may also increase labile $\mathrm{C}$ and $\mathrm{N}$ pools by leaching soluble $\mathrm{C}$ and $\mathrm{N}$ from litter (Cleveland et al. 2004), disrupting soil aggregates (Lundquist et al. 1999, Austin et al. 2004), or releasing nutrients from microbial biomass (from dead cells, cell lysis, and/or release of soluble compounds from live cells; Bottner 1985, Halverson et al. 2000, Fierer and Schimel 2003, Austin et al. 2004). Even small events may stimulate resource pulses: three millimeter events may support microbial activity and only slightly larger events can stimulate plant nutrient uptake and photosynthesis (Sala and Lauenroth 1982, Schwinning and Sala 2004).

Plant community phenology and life span (i.e., annual, biennial, or perennial) also control soil $\mathrm{C}$ and $\mathrm{N}$ pools and fluxes by determining the timing and quantity of nutrient uptake, storage, and release (Cui and Caldwell 1997, Jackson et al. 1988, Hodge et al. 1999, James et al. 2006). These processes further impact soil $\mathrm{C}$ and $\mathrm{N}$ by affecting microbial processes (e.g., mineralization and immobilization) via changes in microbial substrate availability (Woodmansee and Duncan 1980, Rickard 1985a, Jackson et al. 1988, Wedin and Tilman 1990, Hart et al. 1993). It follows that, in conjunction with water availability, the phenology and life span of the dominant species in a plant community should exert substantial control on available soil $\mathrm{C}$ and $\mathrm{N}$ pools.

Bromus tectorum (cheatgrass) invasion provides a unique opportunity to investigate how changing the phenology and life span of the dominant plant species influences the availability of limiting soil resources. A successful and damaging exotic $\mathrm{C}_{3}$ annual grass in the semi-arid western U.S., B. tectorum has recently invaded the low elevation foothills of Colorado's Front Range (Mack 1981, Mack 1986, Brown and Rowe 2007, Adair 2005). Here, B. tectorum replaces native perennial $\mathrm{C}_{3}$ and $\mathrm{C}_{4}$ grasses, effectively altering the phenology and life span of the dominant species by (1) changing the timing of senescence from mid to late summer (perennial $\mathrm{C}_{3}$ and $\mathrm{C}_{4}$ grasses; Singh et al. 1983) to early summer (B. tectorum; Hulbert 1955, Ogle and Reiners 2003) and (2) altering the intra-annual storage of plant $\mathrm{C}$ and nutrients: perennial grasses store $\mathrm{C}$ and nutrients in root systems between growing seasons (Clark and Woodmansee 1992, Ogle and Reiners 2003), while B. tectorum returns all biomass to the soil each year (Rickard 1985b). Such alterations should impact not only soil pools of $\mathrm{C}$ and $\mathrm{N}$, but also microbial processes; senescence in annual grasslands results in higher net $\mathrm{N}$ mineralization than in perennial grasslands because all vegetation turns over annually (Rickard 1985a, Wedin and Tilman 1990). Thus, B. tectorum invasion should alter both the timing of soil resource uptake and the timing and quantity of litter inputs, with cascading effects for microbial communities.

Despite such substantial changes, the overall effect of B. tectorum invasion on soil $\mathrm{C}$ and $\mathrm{N}$ remains unclear: soils been found to have lower, higher, and similar levels of $\mathrm{N}$ and $\mathrm{C}$ beneath $B$. tectorum versus perennial grasses (Bolton et al. 1990, Bolton et al. 1993, Evans et al. 2001, Booth et al. 2003b). These mixed results may be because most $B$. tectorum studies consist of single point, short-term, or laboratory measurements that do not incorporate daily and seasonal variation in abiotic conditions and plant activity. Because replacing perennial grasses with $B$. tectorum likely changes both the overall sizes of available soil $\mathrm{C}$ and $\mathrm{N}$ pools by changing life span (and thus the intra-annual storage of $\mathrm{C}$ and $\mathrm{N}$ in plant biomass) and the seasonal dynamics of these pools by changing phenology, examining how nutrient pools beneath these plant communities interact with time may shed light on these disparate results.

Our goals were to investigate the effects of water, phenology, and life span on soil pools of available and microbial $\mathrm{C}$ and $\mathrm{N}$ and provide critical information regarding the biogeochemical impact of $B$. tectorum. We expected that available and microbial $\mathrm{C}$ and $\mathrm{N}$ pools would be responsive to small rainfall events and that $B$. tectorum invasion would significantly impact overall and seasonal sizes of available soil resource pools. Specifically, we predicted that: (1) given the positive response of microbial activity to small rainfall events in semi-arid ecosystems and frequently observed increases in DOC with soil wetting events, all soil pools of available and 
microbial $\mathrm{C}$ and $\mathrm{N}$ would respond positively (increasing in size) to small simulated rainfall events; (2) across the growing season, the lack of inter-annual storage of $\mathrm{C}$ and $\mathrm{N}$ in living $B$. tectorum biomass would result in more labile $\mathrm{C}$ and $\mathrm{N}$ beneath $B$. tectorum than perennial grasses; (3) pools of plant and microbially available soil $\mathrm{C}$ and $\mathrm{N}$ pools would be greater beneath senesced versus active plant communities due to reduced plant uptake and increased litter inputs; and (4) we would find the most and largest between-community differences in soil pools when the phenological difference between these communities was also greatest.

\section{Methods}

To test our hypotheses, we conducted an experiment in neighboring communities dominated by $B$. tectorum and native $\mathrm{C}_{3}-\mathrm{C}_{4}$ perennial grasses. Three times during the growing season, we measured the responses of six soil $\mathrm{C}$ and $\mathrm{N}$ pools beneath each community to small artificial rainfall events: ammonium and nitrate, the primary forms plant-available $\mathrm{N}$; dissolved organic $\mathrm{C}$ (DOC) and $\mathrm{N}(\mathrm{DON})$, the primary substrates for microbial growth (and perhaps available to plants; Jones et al. 2005, Harrison et al. 2008); and microbial $\mathrm{C}$ and $\mathrm{N}$, the "pool" responsible for $\mathrm{C}$ and $\mathrm{N}$ mineralization.

Site selection and experimental design

We conducted this experiment in the semi-arid ponderosa pine-grassland ecotone of the Rocky Mountains foothills in Horsetooth Mountain Park (HTMP; $40^{\circ} \mathrm{N}, 105^{\circ} \mathrm{W}$; Larimer County Parks, Colorado). Mean annual precipitation is $430 \mathrm{~mm}$ and mean annual temperature is $8.5^{\circ} \mathrm{C}$ (NCDC 2005). Soils at all sites are of the Ratake-Rock outcrop complex (Soil Survey Staff 2007). Soils in this complex are well drained, shallow rocky loams with very low water holding capacity (Soil Survey Staff 2007). Beginning in the late 1800 s, the land within HTMP was used for recreation, timber harvesting, grazing, and farming (LCPOL 2006). After its establishment as a park in 1982, land within HTMP was set aside for recreation, although some grazing continued until 1994 (LCPOL 2006). Little information exists regarding the invasion and spread of $B$. tectorum in the park, but B. tectorum was abundant and acknowledged as a conservation risk in HTMP by 1999 (LCPOL 2006, CHNP 1999).

Within HTMP, we randomly selected 4 sites from all south-facing areas that contained a mix of native $\mathrm{C}_{3}$ and $\mathrm{C}_{4}$ grasses and were free of $B$. tectorum, as well as adjacent areas dominated by $B$. tectorum. Native plots were dominated by a mixture of the native perennial grasses Stipa comata, Stipa robusta, Andropogon gerardii, Bouteloua gracilis, and Bouteloua curtipendula. As determined by the hydrometer method, all sites had sandy loam soils, with no significant differences between native and exotic plots at the four sites in percent sand, silt, or clay content (paired t-test, all $P>0.4$ ). All sites were located within $6 \mathrm{~km}^{2}$, between $1768-1817 \mathrm{~m}$ in elevation.

In June, we randomly selected $121 \mathrm{~m}^{2}$ plots at each of the four sites, half in native bunchgrass vegetation $\left(\mathrm{C}_{3}-\mathrm{C}_{4}\right.$ mix $)$ and half in areas dominated by B. tectorum ( $>80 \%$ of plant cover). Two plots from each vegetation type were each randomly assigned to one of three experiment periods (four plots per experiment period): June, July, or August 2003. Within each period, one of the two plots in each vegetation type was randomly selected as the control. The other received a $5 \mathrm{~mm}$ simulated rainfall event. We chose an event of this size because events $\leq 5 \mathrm{~mm}$ comprise more than $70 \%$ of all rainfall events and account for approximately $25 \%$ of total rainfall in this ecosystem (NCDC 2005). The specific dates of each experimental period were selected by choosing a time period that (1) had been free of significant precipitation for 2 days in June and at least 10 days in July and August and (2) had a dry weather forecast for the following 4 days. Because extended precipitation-free periods are rare in June, the pre-experimental dry period was much shorter than in July and August (NCDC 2005).

Experiments began on June 9, July 2, and August 21. There were no natural precipitation events during the experiment periods. In general, mean temperature increased and soil moisture decreased from the June to August experimental periods. Mean air temperature during the experimental periods in June, July, and August was $18.3^{\circ} \mathrm{C}, 25.6^{\circ} \mathrm{C}$, and $23.6^{\circ} \mathrm{C}$. Soil temperature was measured in July and August, on days $2-4$ of the experiment. Mean soil temperature increased from $21.7^{\circ} \mathrm{C}$ in July to $22.8^{\circ} \mathrm{C}$ in August. Ambient soil moisture (i.e., in control plots) during 
the experimental periods averaged $9.6 \%$ in June, $3.8 \%$ in July, and $1.8 \%$ in August.

At sunrise on the first day of each experiment, we applied water to the two treatment plots at each site with a watering can, being careful to prevent soil compaction and runoff. Six hours later, and each day thereafter for 3 days, we collected four soil cores from each plot (5 cm diameter, 0-5 cm depth). Our sampling regime resulted in four samples per plot per day, for a total of 256 samples per sampling period (768 across all sampling periods). On days 2-4 in June and July, we measured soil temperature in each of the four soil sampling locations prior to soil core collection. We transported soil samples to the lab where they were processed and/or extracted within $6 \mathrm{~h}$ of collection. Soils were sieved to remove large debris and gravel $>2 \mathrm{~mm}$ and analyzed for gravimetric water content, extractable inorganic $\mathrm{N}$, extractable DOC and DON, and microbial biomass $\mathrm{C}$ and $\mathrm{N}$ by chloroform fumigation extraction (Brookes et al. 1985). Repeating our measurements daily over 4 days allowed us incorporate daily variation in these pools into our analysis (to determine whether the treatment effects were consistent or changed across days). It also allowed us to capture the full response of soil pools to the simulated rainfall event (Fig. 1).

We extracted $20 \mathrm{~g}$ subsamples from each core with $100 \mathrm{~mL}$ of $0.5 \mathrm{M} \mathrm{K}_{2} \mathrm{SO}_{4}$. We fumigated another $20 \mathrm{~g}$

(a)

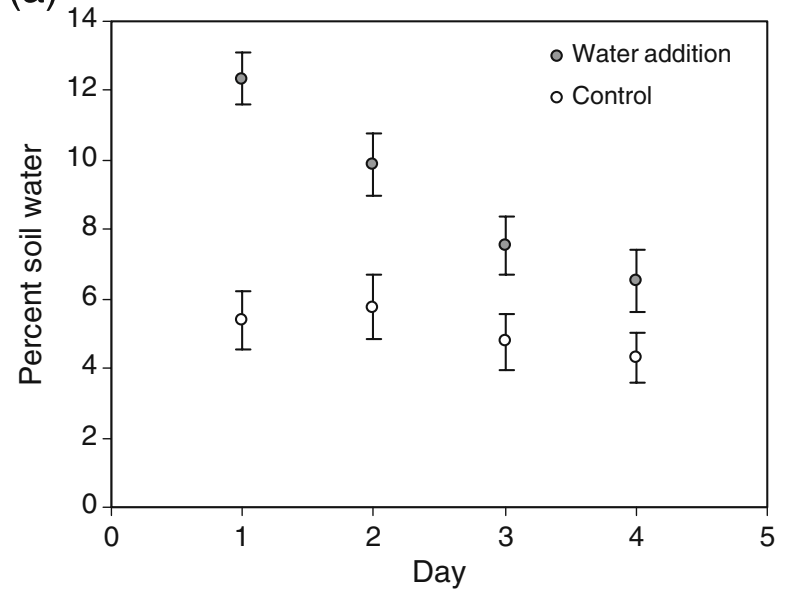

Fig. 1 Percent soil water a by day, averaged across month and plant community type $(n=24 ; \mathrm{BT}=B$. tectorum, $\mathrm{PG}=$ native perennial grasses), and $\mathbf{b}$ averaged across day and plant activity (active or inactive), for each plant community and water treatment. "Active" refers to months during which either plant subsample with chloroform for 5 days and extracted it with $0.5 \mathrm{M} \mathrm{K}_{2} \mathrm{SO}_{4}$. Soil-extract mixtures were shaken for $1 \mathrm{~h}$, filtered, and analyzed for total organic $\mathrm{C}$ and total $\mathrm{N}$ using a Shimadzu TOC/TN analyzer (Shimadzu, Columbia, MD, USA). Microbial $\mathrm{C}$ and $\mathrm{N}$ were calculated using a $\mathrm{K}_{\mathrm{ec}}$ of 0.45 (Beck et al. 1997) and $a \mathrm{~K}_{\mathrm{en}}$ of 0.54 (Brookes et al. 1985). Extractable DOC was defined as the total organic $\mathrm{C}$ of the nonfumigated extracts. We analyzed non-fumigated extracts for inorganic $\mathrm{N}$ using an Alpkem autoanalyzer (Alpkem, College Station, TX). Extractable DON was calculated as the difference between total and inorganic N. As with inorganic nutrients, using a salt solution to remove organic $\mathrm{C}$ and $\mathrm{N}$ pools from soils extracts more DOC and DON than does using water (Sparks 1996, Jones and Willett 2006). However, DOC and DON pool sizes from $0.5 \mathrm{~K}_{2} \mathrm{SO}_{4}$ extracts have been found to be very similar to those from $2 \mathrm{M} \mathrm{KCl}$ extracts (Jones and Willett 2006).

\section{Statistical analysis}

Because our hypotheses sought to explain the differences in soil $\mathrm{C}$ and $\mathrm{N}$ pools beneath (1) active versus inactive plant communities and (2) B. tectorum versus native perennial grass communities, we combined "month" and "plant community" information into one class variable that gave each month and plant

(b)

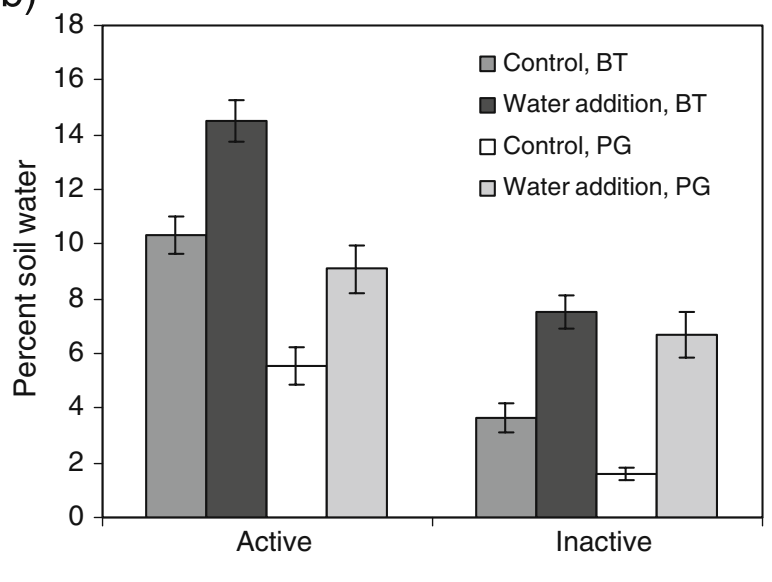

community was actively growing; "inactive" refers months during which either plant community was senesced. For active BT and inactive PG, $n=16$ (i.e., 16 values were averaged); for inactive BT and active PG, $n=32$. Error bars are \pm 1 standard error 
community combination a unique number (MPC; 6 classes). We then used a mixed model ANOVA with repeated measures (day), site and plot as random effects, and water treatment and MPC as fixed effects (proc MIXED ANOVA, SAS). We performed this analysis on the average daily size of each $\mathrm{C}$ and $\mathrm{N}$ pool in each plot (i.e., the four daily plot samples were averaged for a total of one value per plot per day, 64 values per experimental period). We used Akaike's Information Criterion, adjusted for small sample size (AICc), to choose the appropriate covariance structure for each soil pool (Table 1; Burnham and Anderson, 2002). We then used "estimate" statements to compare soil pool sizes beneath active versus inactive communities ( $B$. tectorum was active in June and senesced in July and August; $\mathrm{C}_{3}-\mathrm{C}_{4}$ grasses were active June-July and senesced in August) and beneath B. tectorum versus perennial grass communities (Proc MIXED, SAS). These estimate statements also provided estimates of the mean differences between plant communities and periods of plant activity. This analysis allowed us to directly address our predictions that soil pools of $\mathrm{C}$ and $\mathrm{N}$ would be (1) greater beneath inactive versus active plant communities (across plant community type; rather than merely examining change by month) and (2) larger beneath $B$. tectorum than native perennial grasses.

Statistically significant responses to the water treatment would indicate that soil $\mathrm{C}$ and $\mathrm{N}$ pools were responsive to small rainfall events. If MPC was statistically significant, we further examined pool size differences beneath each plant community by month using estimate statements with a Bonferroni adjustment. If the number or sizes of statistically significant differences in pool sizes between plant communities were greatest when the between-community phenological difference was also the greatest (July), our hypothesis that plant phenology influences the size of available and microbial soil $\mathrm{C}$ and $\mathrm{N}$ pools would be further supported. We also examined any significant relationships among water, day, and/or MPC.

We calculated the $\mathrm{R}^{2}$ for each ANOVA with and without the random effects of site and plot. The difference between these values indicates the proportion of the variance due to random (unmeasured) site and plot effects. The $\mathrm{R}^{2}$ calculated without random effects is more closely related to the proportion of the variance that is explained by the experimental treatments.

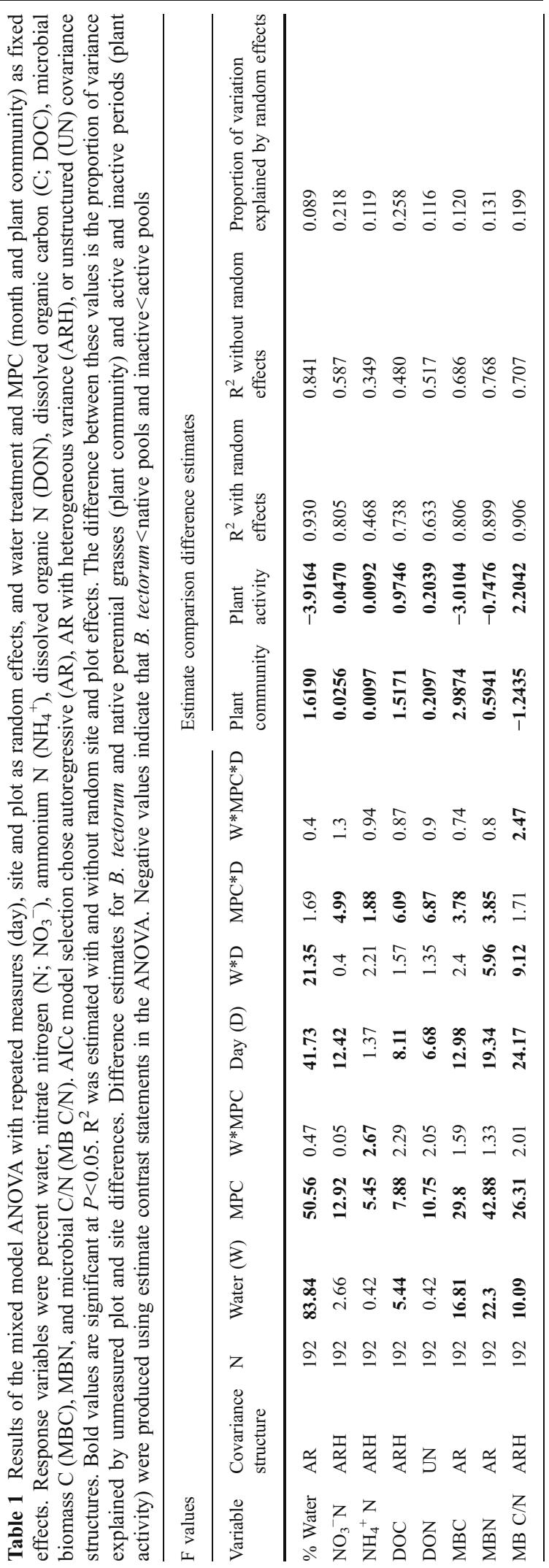


To examine statistically significant patterns, we calculated the relative effects of water additions, plant community, and plant activity on $\mathrm{C}$ and $\mathrm{N}$ pools. We calculated the water effect by dividing the mean pool size of the water addition plots by that of the control plots. We calculated plant community and activity effects by dividing the mean pool size of $B$. tectorum or inactive plant communities by the mean pool size of native or active plant communities.

Unfortunately, our limited soil temperature data did not allow us to include this variable in our repeated measures ANOVA. However, we performed the same repeated measures ANOVA for soil temperature, and found that soil temperature did not change significantly between plant communities $(P>0.05)$, although it did change significantly with day $(P<0.0001)$ and water treatment $(P=0.004)$. Although these results indicated that soil temperature was correlated with water treatment, we then performed the repeated measures ANOVA with soil temperature as a covariate; our analysis of this limited data revealed that the soil temperature did not significantly affect any soil C or N pool (in July and Aug, days 2-4). Despite these results, as a primary driver of soil microbial processes, soil temperature should be an important explanatory variable for soil $\mathrm{C}$ and $\mathrm{N}$ pools. Unfortunately, our limited data do not allow us to test this hypothesis exhaustively, and, in our current analysis, variation resulting from changes in temperature (or other abiotic variables) would be incorporated into the variable "day", random site and plot variation, or unexplained variance.

Because we do not have pre-invasion soil pool information, our invasion results may be influenced by pre-invasion plot-level differences. We attempted to control for such differences by selecting proximate within-site plots with similar soils, slope, and topography, without major rock or shrub components. Further, it seems unlikely that our results are due to pre-invasion differences, as soil pools of $\mathrm{C}$ and $\mathrm{N}$ (except DON) were not consistently larger beneath $B$. tectorum than native perennial grasses but fluctuated with phenology and month (see Results).

\section{Results}

Water additions, plant community and month (MPC), day, and random site and plot effects explained a large proportion of the variation in soil $\mathrm{C}$ and $\mathrm{N}$ pools $\left(\mathrm{R}^{2}=\right.$ 0.47-0.93; Table 1). From 9-26\% of the variation in all soil pools was associated with random effects, indicating that we did not measure all variables that control the observed plot and site differences in soil $\mathrm{C}$ and $\mathrm{N}$ pools (e.g., temperature or other abiotic variables; Table 1).

\section{Soil moisture}

On average, simulated rainfall events more than doubled soil water $(0-5 \mathrm{~cm})$ on the day of watering (significant water effect; Fig. 1a). The effect of water treatments varied by day (significant water by day interaction; Table 1), with a trend for soils in water addition plots to start much wetter than control plots and become drier each day thereafter (Fig. 1a). In contrast soil moisture in control plots tended to be lower and vary less (Fig. 1a).

Across all treatments, soil moisture was highest early in the growing season, when plant communities were active, and lowest later in the growing season, when plants were inactive (significant MPC effect; Fig. 1b). Soil moisture in control (non-water addition) plots declined linearly with month $\left(\mathrm{R}^{2}=0.635, P<\right.$ 0.0001 ) and decreased by nearly $60 \%$ from active to inactive periods. Soil moisture was also significantly higher beneath $B$. tectorum than perennial grasses in all months (significant plant community effect; Table 1; Fig. 1b).

Sensitivity of soil pools to pulse events and soil moisture

In both plant communities, water additions consistently significantly increased microbial $\mathrm{C}$ and $\mathrm{N}$ and significantly reduced DOC by an average of $15 \%$ (Tables $1 \& 2$ ). Ammonium and microbial $\mathrm{C} / \mathrm{N}$ had more complex responses to water treatments that varied with month, plant community, and/or day (significant MPC interactions with water or water and day; Table 1).

Labile $\mathrm{N}$ pools did not respond strongly to water additions. Soil nitrate and DON did not respond to the water treatment and the relatively weak effect of water additions on ammonium was inconsistent through time and between plant communities (significant MPC by water effect; Table 1, Fig. 2a). In $B$. tectorum stands, the trend was for water additions to 


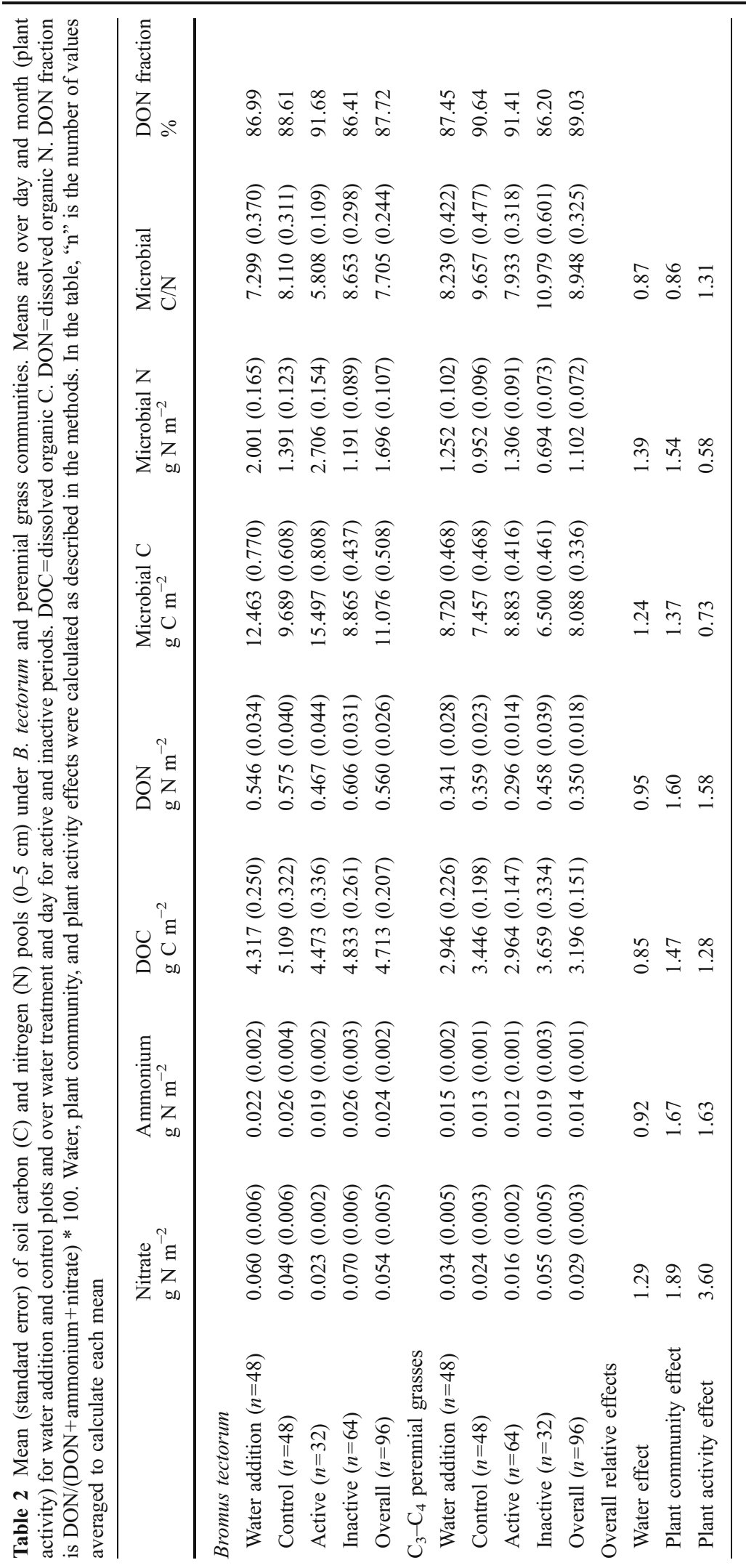



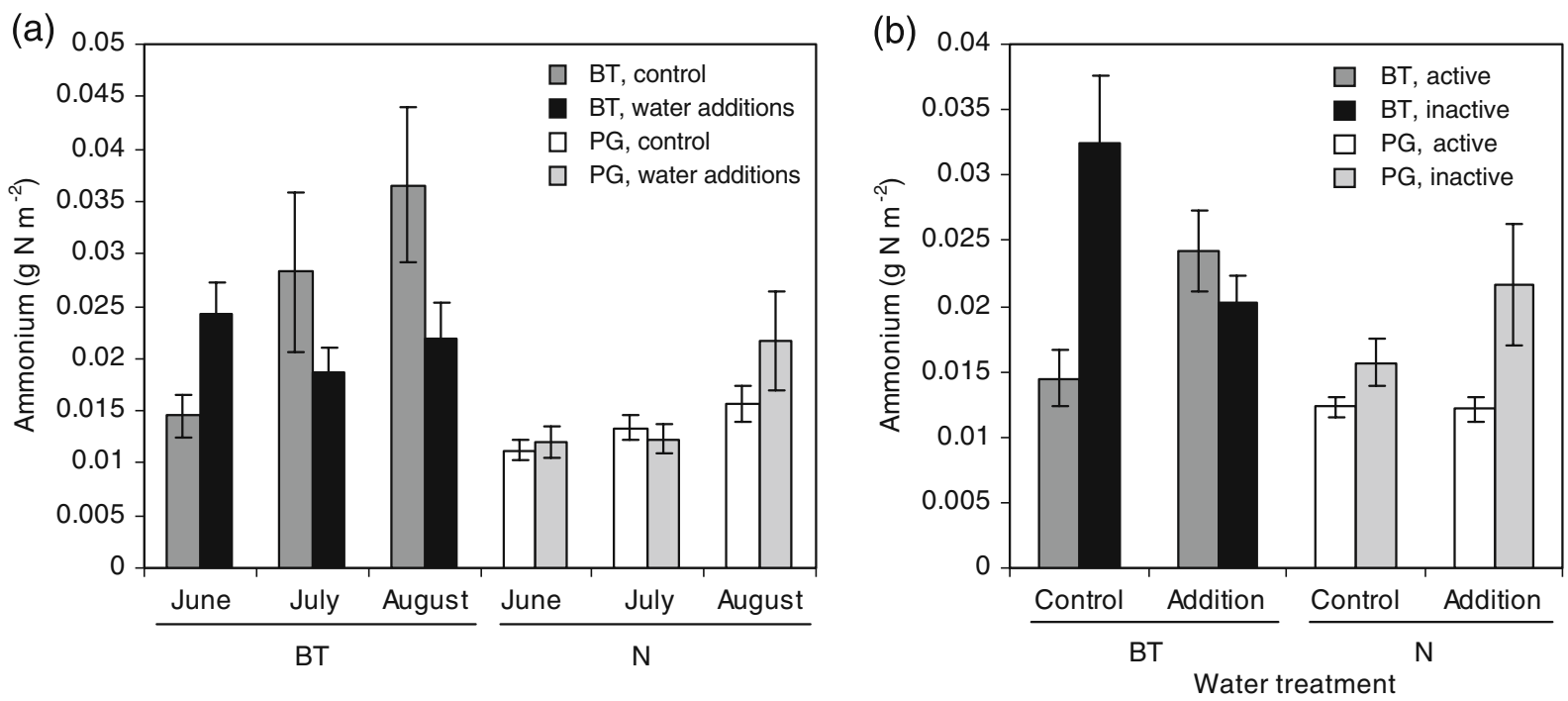

Fig. 2 Mean ammonium nitrogen $(\mathrm{N})$ beneath $B$. tectorum (BT) and perennial grass communities (PG; error bars are \pm 1 $\mathrm{SE})$ a by water treatment (control or addition) and month $(n=$

slightly increase ammonium during active months (June), but slightly decrease ammonium during inactive months (July and August; Fig. 2); in native communities, water additions appeared to have little or no effect on ammonium regardless of plant activity level (significant MPC by water effect; Fig. 2a).

In both plant communities, during active and inactive months, microbial pools of $\mathrm{C}$ and $\mathrm{N}$ responded strongly to water additions. Overall, water additions significantly increased microbial $\mathrm{C}$ by an average of $24 \%$ and microbial $\mathrm{N}$ by an average of $39 \%$ (significant water effect; Table 1). The effect of

(a)

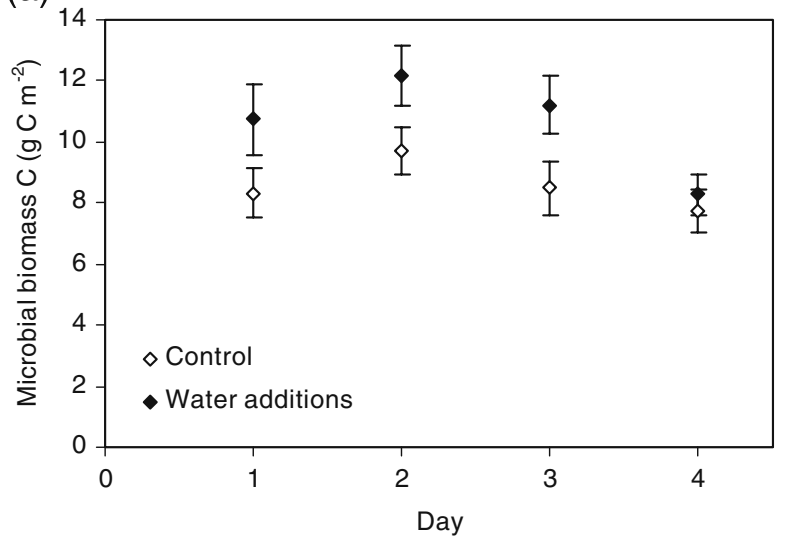

16 for all means) and $\mathbf{b}$ water treatment and plant activity (active or inactive; $n=16$ for active $\mathrm{BT}$ and inactive PG; $n=32$ for inactive BT and active PG)

the water treatment on microbial pools varied significantly with day (Table 1). For microbial $\mathrm{C}$ and N, the trend was for water treatments to increase these pools substantially on day one (30\% and $50 \%$ increases for microbial $\mathrm{C}$ and $\mathrm{N}$ ), followed by a daily decrease in microbial $\mathrm{C}$ and $\mathrm{N}$ to control plot levels by day four (this trend was significant for microbial $\mathrm{N}$, but was only marginally significant for C; Table 1; Fig. 3). The effect of water on microbial $\mathrm{C} / \mathrm{N}$ ratios varied through time with day and month and with plant community (significant water by MPC by day effect; Table 1). During June, ambient soil moisture levels

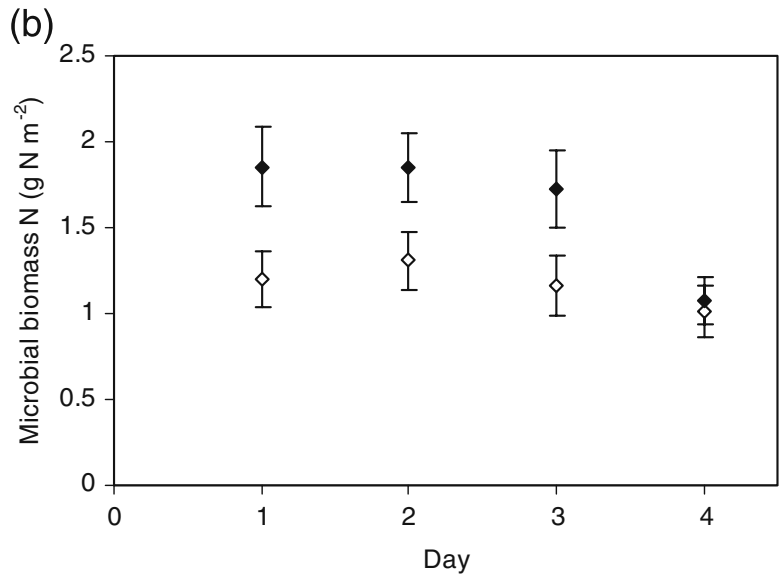

Fig. 3 Microbial biomass a carbon $(\mathrm{C})$ and $\mathbf{b}$ nitrogen $(\mathrm{N})$ by day, averaged across plant community and all months (for all means, $n=$ 24). Error bars are \pm 1 standard error 
were high and all plant communities and water treatments tended to have low daily $\mathrm{C} / \mathrm{N}$ ratios; water additions appeared to have no consistent effect on microbial C/N (Fig. 4a). When soils were dry in July and August, water additions tended to decrease microbial $\mathrm{C} / \mathrm{N}$ across plant communities by an average of $70 \%$ on day one (Fig. 4b, c). Microbial $\mathrm{C} / \mathrm{N}$ then tended to increase daily in each plant community, but at varying rates, as soils dried (Fig. 4b, c).

Within both water treatments, microbial pools were very responsive to soil moisture. Over the entire sampling period, percent soil water explained $45.4 \%$, $61.5 \%$, and $49.5 \%$ of the variation in microbial $\mathrm{C}, \mathrm{N}$, and $\mathrm{C} / \mathrm{N}$ (respectively; $P<0.05$; linear regressions). Microbial $\mathrm{C}$ and $\mathrm{N}$ increased, and $\mathrm{C} / \mathrm{N}$ decreased, significantly with increasing soil water, while other soil $\mathrm{C}$ and $\mathrm{N}$ pools were much less responsive. Correlations between soil moisture and nitrate, DON, and DOC were significant, but explained $<3 \%$ of the variation in these data. Ammonium was not significantly correlated with percent soil water.

Plant community and soil pools of $\mathrm{C}$ and $\mathrm{N}$

All soil $\mathrm{C}$ and $\mathrm{N}$ pools were significantly larger beneath $B$. tectorum than native perennial $\mathrm{C}_{3}-\mathrm{C}_{4}$ grass communities (Tables 1 and 2). Averaged over plant activity and water treatment, ammonium, nitrate, DOC, and DON were 47-89\% larger beneath $B$. tectorum than native communities. Microbial $\mathrm{C}$ and $\mathrm{N}$ were $37 \%$ and $54 \%$ larger beneath $B$. tectorum than native communities. Regardless of plant community, activity, or water treatment, DON made up a large fraction of extractable $\mathrm{N}$ (Table 2). Excluding microbial N, DON was $88 \%$ of extractable N. Microbial $\mathrm{C}$ and $\mathrm{N}$ pools were 2 to 3.5 times larger than DOC and DON pools.

However, during inactive months, the effect of plant community on ammonium tended to be reduced by the water treatment (significant MPC by water interaction; Table 1). Water additions during inactive months appeared to have little effect on ammonium beneath native grasses, but had small negative effects on ammonium beneath $B$. tectorum, resulting in similar levels of ammonium beneath native and $B$. tectorum water addition plots (Fig. 2).

Microbial $\mathrm{C} / \mathrm{N}$ ratios tended to be lower beneath $B$. tectorum stands than perennial grass communities, but again, in June when soils were moist and $\mathrm{C} / \mathrm{N}$ ratios low, plant community appeared to have no consistent effect in either water treatment (significant MPC by water by day interaction; Fig. 4a). In July and August, daily $\mathrm{C} / \mathrm{N}$ ratios in both water treatments tended to be either equal or lower beneath $B$. tectorum than beneath native perennial grasses (Fig. $4 b, c$ ).

All soil $\mathrm{C}$ and $\mathrm{N}$ pools had a significant interaction between MPC and day (Table 1). On each day within each month, ammonium, nitrate, DOC, and microbial $\mathrm{C}$ and $\mathrm{N}$ pools beneath $B$. tectorum stands tended to be larger than or equal to soil pools beneath native communities. DON pools always appeared larger beneath $B$. tectorum than native grass, but the size of the difference varied daily. All other soil pools appeared equal beneath the two communities on only one (ammonium and microbial $\mathrm{C}$ and $\mathrm{N}$ ) or two (nitrate and DOC) days across all three sampling periods. (a)

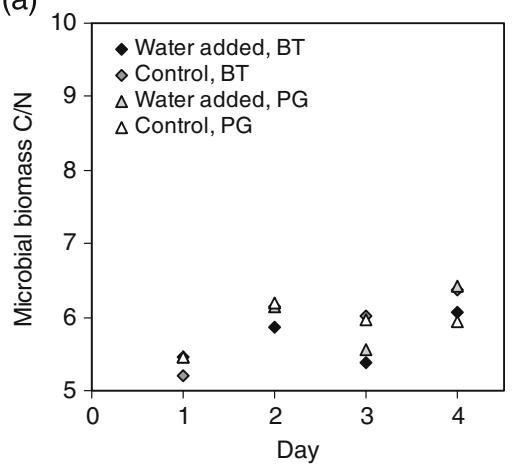

(b)

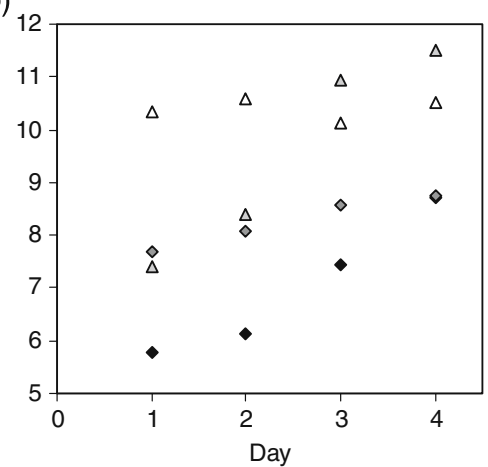

(c)

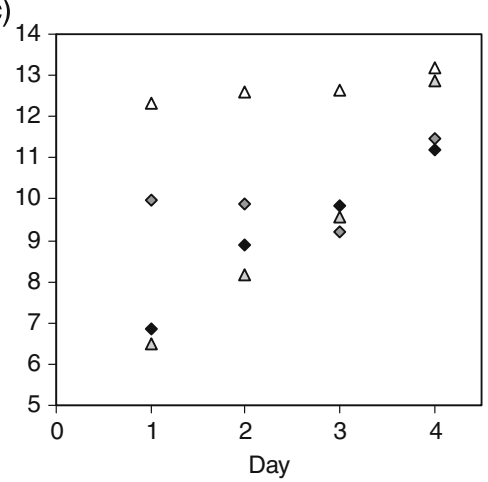

Fig. 4 Average microbial biomass $\mathrm{C} / \mathrm{N}$ ratio each day by plant community (B. tectorum, BT, or perennial grass community, PG) and water treatment $(n=4)$ in a June, b July, and $\mathbf{c}$ August 
Table 3 Estimated mean differences between soil pools beneath B. tectorum and native grass communities by month (ANOVA estimate statement). Negative values indicate that pools were larger (or values were greater) under native versus B. tectorum communities. Positive values indicate that pools were larger under B. tectorum than native communities. Bold values indicate
Bonferroni adjusted significant differences between plant communities. $\mathrm{NO}_{3}{ }^{-} \mathrm{N}=$ nitrate nitrogen $(\mathrm{N}) . \mathrm{NH}_{4}{ }^{+} \mathrm{N}=$ ammonium $\mathrm{N}$. $\mathrm{DOC}=$ dissolved organic carbon $(\mathrm{C}) . \mathrm{DON}=$ dissolved organic $\mathrm{N}$. $\mathrm{MBC}=$ microbial biomass $\mathrm{C} . \mathrm{MBN}=$ microbial biomass $\mathrm{N}$. $\mathrm{MB} \mathrm{C} /$ $\mathrm{N}=$ microbial biomass $\mathrm{C} / \mathrm{N}$ ratio

\begin{tabular}{|c|c|c|c|c|c|c|c|}
\hline & $\begin{array}{l}\mathrm{NO}_{3}{ }^{-} \mathrm{N} \\
\mathrm{g} \mathrm{N} \mathrm{m}^{-2}\end{array}$ & $\begin{array}{l}\mathrm{NH}_{4}^{+}{ }^{+} \\
\mathrm{g} \mathrm{N} \mathrm{m}^{-2}\end{array}$ & $\begin{array}{l}\text { DOC } \\
\mathrm{g} \mathrm{C} \mathrm{m}^{-2}\end{array}$ & $\begin{array}{l}\mathrm{DON} \\
\mathrm{g} \mathrm{N} \mathrm{m}^{-2}\end{array}$ & $\begin{array}{l}\mathrm{MBC} \\
\mathrm{g} \mathrm{C} \mathrm{m}^{-2}\end{array}$ & $\begin{array}{l}\mathrm{MBN} \\
\mathrm{g} \mathrm{N} \mathrm{m}^{-2}\end{array}$ & $\mathrm{MB} \mathrm{C} / \mathrm{N}$ \\
\hline June & 0.006 & 0.008 & 2.071 & 0.215 & 5.131 & 0.903 & -0.079 \\
\hline July & 0.038 & 0.011 & 1.426 & 0.217 & 2.751 & 0.681 & -2.335 \\
\hline August & 0.033 & 0.011 & 1.055 & 0.197 & 1.080 & 0.198 & -1.316 \\
\hline
\end{tabular}

Plant community activity and soil pools of $\mathrm{C}$ and $\mathrm{N}$

All soil pools of available $\mathrm{C}$ and $\mathrm{N}$ were greater when plant communities were inactive than when they were active (Tables 1 and 2). Nitrate pools were more than three times larger after senescence than during periods of active plant growth (Table 2). After senescence, ammonium, DOC, and DON pools increased by $28-$ $63 \%$ (Table 2). However, as described previously, in $B$. tectorum communities, the contrasting effect of water additions on ammonium during active versus inactive periods resulted in a negligible plant activity effect in B. tectorum water addition plots (MPC by water interaction; Fig. 2b).

In contrast, microbial $\mathrm{C}$ and $\mathrm{N}$ decreased by $27 \%$ and $42 \%$ during months when native grasses or $B$. tectorum were inactive (Tables 1 and 2). At the same time, microbial $\mathrm{C} / \mathrm{N}$ ratios increased from an average of 7 to an average of 10 after senescence (Tables 1 and 2).

All soil pools of $\mathrm{C}$ and $\mathrm{N}$ varied significantly with month and plant community (MPC; Table 1). The size of the between-community difference was not always greatest during the month of greatest phenological difference (July); only nitrate, DON, and microbial C/ $\mathrm{N}$ ratios showed the largest differences in July (Table 3). However, we did find the greatest number of statistically significant between-community differences during this period: all soil pools were significantly larger beneath $B$. tectorum than perennial grasses in July (Table 3). In June, only DOC, DON, and microbial $\mathrm{C}$ and $\mathrm{N}$ pools were significantly larger beneath $B$. tectorum than perennial grasses. In August, only nitrate, ammonium, and DON were significantly larger beneath $B$. tectorum than perennial grasses.

\section{Discussion}

Sensitivity of soil pools to pulse events

Microbial pools responded strongly to water additions while labile pools of soil $\mathrm{C}$ and $\mathrm{N}$ responded only weakly, or not at all. As we expected, microbial $\mathrm{C}$ and $\mathrm{N}$ increased, and $\mathrm{C} / \mathrm{N}$ ratios decreased, with water additions and percent soil water, confirming that microbial pools in this ecosystem, as in other arid and semi-arid ecosystems, are strongly water limited (Austin et al. 2004, Ford et al. 2007). Given that bacteria have lower $\mathrm{C} / \mathrm{N}$ ratios $(\sim 4)$ than fungi $(\sim 10)$, our results suggest that small rainfall events may increase the bacterial to fungal ratio of the microbial community (Sterner and Elser 2002). Alternatively, water additions may lower $\mathrm{C} / \mathrm{N}$ ratios by increasing microbial substrate $\mathrm{N}$ availability and uptake (Killham 1994, Zak et al. 1999, Sterner and Elser 2002). As soils dried after water treatments, microbial $\mathrm{C}$ and $\mathrm{N}$ decreased and $\mathrm{C} / \mathrm{N}$ ratios increased. Again, the increasing $\mathrm{C} / \mathrm{N}$ ratios may be a result of changing community composition and/or reduced access to $\mathrm{N}$ as soils dry and soil water films contract (Sterner and Elser 2002, Ford et al. 2007).

We expected that our simulated rainfall event would increase DOC due to increased organic matter leaching, breakup of soil aggregates, or release of labile C from dead or previously dry, live microorganisms (Bottner 1985, Halverson et al. 2000, Fierer and Schimel 2003, Austin et al. 2004). Instead, water additions decreased DOC by an average of $15 \%$. At the same time, water increased microbial biomass by an average of $30 \%$, suggesting that DOC declines could be related to coincident microbial growth. On average, water additions decreased DOC 
by $0.65 \mathrm{~g} \mathrm{C} \mathrm{m}^{-2}$ while microbial biomass increased by approximately $2 \mathrm{~g} \mathrm{C} \mathrm{m}^{-2}$, suggesting that water additions may release DOC from organic matter, but that water-induced $\mathrm{C}$ uptake by microbes is likely larger than any concurrent DOC increase.

Contrary to our expectations, pools of available $\mathrm{N}$ responded weakly (ammonium) or not at all (nitrate and DON) to simulated small rainfall events. This lack of responsiveness may reflect the inability of plants to utilize events of this size for inorganic $\mathrm{N}$ uptake (Schwinning and Sala 2004). Alternatively, it may reflect essentially balanced fluxes of $\mathrm{N}$ mineralization and plant/microbial $\mathrm{N}$ uptake. The relatively large increase in microbial biomass $\mathrm{N}\left(0.45 \mathrm{~g} \mathrm{~N} \mathrm{~m}^{-2}\right)$ suggests that microbial $\mathrm{N}$ uptake may have "swamped out" any water-induced changes in the processes that produce DON, ammonium, and nitrate, resulting in no overall change in these $\mathrm{N}$ pools on a daily time scale (e.g., extracellular enzyme activity and mineralization).

With the exception of ammonium, water additions had similar effects on soil $\mathrm{C}$ and $\mathrm{N}$ pools in both plant communities suggesting that $B$. tectorum invasion does not change the response of microbial and most labile pools to small rainfall events. However, our results suggest that $B$. tectorum invasion may increase the responsiveness of ammonium to small rainfall events, increasing soil ammonium during active periods and decreasing it after senescence. Overall, our results are consistent with research that suggests microbial communities respond quickly to small rainfall events (Austin et al. 2004, Schwinning and Sala 2004).

Changing phenology and life span: Bromus tectorum effects on soil resource pools

Across the growing season, all labile and microbial pools of $\mathrm{C}$ and $\mathrm{N}$ were larger beneath $B$. tectorum than perennial grasses, suggesting that the replacement of a perennial by annual community increases the size of these pools. Microbial $\mathrm{C} / \mathrm{N}$ ratios were lower beneath $B$. tectorum than perennial grasses. High quality substrates generally produce low fungal/ bacterial ratios (Bossuyt et al. 2001). The larger labile $\mathrm{N}$ pools we found beneath $B$. tectorum suggest that microbes had access to higher quality substrates, which could produce communities with lower fun$\mathrm{gal} / \mathrm{bacterial}$ ratios or fungal communities with lower $\mathrm{C} / \mathrm{N}$ ratios (Sterner and Elser 2002). Belnap et al. (2005) found more active bacteria and less fungal richness in soils beneath $B$. tectorum than perennial grasses.

An unexpected result was that DON made up nearly $90 \%$ of the extractable $\mathrm{N}$ pool. Even if only $10 \%$ of DON is labile (Jones et al. 2004), it would still make up $45 \%$ of available $\mathrm{N}$ (where available $\mathrm{N}$ is all mineral $\mathrm{N}$ plus $10 \%$ of DON). Water induced declines in DON (although not statistically significant) and increases in microbial $\mathrm{N}$ (and decreases in $\mathrm{C} / \mathrm{N}$ ratios), suggest that at least a small fraction of DON is available to microbes or plants on this time scale.

Soil pools of $\mathrm{C}$ and $\mathrm{N}$ changed seasonally and in response to plant activity levels. As we expected, all labile $\mathrm{C}$ and $\mathrm{N}$ pools increased after senescence, likely due to reduced plant uptake and increased litter inputs. Since ammonium and nitrate are the forms of $\mathrm{N}$ most available to plants, it is likely that postsenescence increases were associated with reduced plant uptake. DOC and DON most likely increased due to post-senescence litter inputs.

Research indicates that inorganic $\mathrm{N}$ and DOC accumulate during dry periods (Fisher et al. 1987, Edmonds 2004, Welter et al. 2005); we also found inorganic N, DOC, and DON to increase from June to August (active to inactive periods). In this ecosystem, July and August are hot and dry (NCDC 2005). While the accumulation of $\mathrm{C}$ and $\mathrm{N}$ during post-senescent dry periods was likely a response to decreased plant uptake and increased litter inputs, it may have also been associated with the accumulation of inorganic $\mathrm{N}$ from dry deposition (Fenn et al. 2003), limited microbial C and N mineralization (Fisher et al. 1987), and photochemical litter decomposition (Austin and Vivanco 2006, Brandt et al. 2007).

In contrast, microbial $\mathrm{C}$ and $\mathrm{N}$ decreased during inactive periods, while $\mathrm{C} / \mathrm{N}$ ratios increased. This semiarid ecosystem becomes increasingly hot and dry from June to August, a trend evidenced by decreasing soil water in control soils over the same period. Microbial C and $\mathrm{N}$ increased, and $\mathrm{C} / \mathrm{N}$ ratios decreased, strongly in response to our water treatment and with increasing percent soil moisture. Thus, microbial pools were likely responding to changes in soil water rather than plant activity. The remaining soil pools were not strongly affected by soil water content, suggesting that plant phenology (uptake and/or litter inputs) was the primary influence on the size of these pools.

While $\mathrm{C}$ and $\mathrm{N}$ pools were larger beneath $B$. tectorum than perennial grasses overall, for all pools 
but DON, this was not true within all months. Although the size of the between-community difference in soil pools was not always largest when the between-community phenological difference was greatest (July), we did find the largest number of statistically significant differences during this time, further supporting a strong role for phenology and plant life span in controlling soil pools of $\mathrm{C}$ and $\mathrm{N}$.

Examining how nutrient pools beneath these plant communities interacted with time did shed light on previous, disparate results regarding the effects of $B$. tectorum invasion of perennial grasslands. Our overall results of larger pools of inorganic $\mathrm{N}$ beneath $B$. tectorum versus perennial grasses were consistent with two other multiple-measurement studies that also found higher levels of inorganic $\mathrm{N}$ beneath $B$. tectorum than perennial grasses (Booth et al. 2003b, Sperry et al. 2006). However, three single year studies in Utah found largely similar inorganic $\mathrm{N}$ levels beneath $B$. tectorum and perennial grasses (Evans et al. 2001, Miller et al. 2006, Hooker et al. 2008). Unlike Colorado's Front Range, in Utah, B. tectorum invades areas dominated by $\mathrm{N}$ fixing biological soil crusts. Invasion may therefore reduce $\mathrm{N}$ input and conservation by reducing the cover of these crusts (Belnap et al. 2006). Another study, conducted 1 day per month for three months in 2 years found no difference in inorganic $\mathrm{N}$ beneath $B$. tectorum and perennial grasses, a contrasting result that could be due to failure of this study to capture daily variation or variation in soil water availability (Svejcar and Sheley 2001).

Consistent with the results of Booth et al. (2003b) and Belnap and Phillips (2001), we found similar levels of inorganic $\mathrm{N}$ pools beneath both plant communities in mid-to late-spring (June). Early spring studies have found lower inorganic $\mathrm{N}$ levels beneath B. tectorum than perennial grasses (Evans et al. 2001 and Rimer and Evans 2006 at the same site), likely due to early spring draw down of soil resources by $B$. tectorum, which develops roots extensively during the fall and early spring and becomes active earlier than many native perennial species (Harris 1967, Kremer and Running 1996, Booth et al. 2003a). In July and August, inorganic $\mathrm{N}$ pools were larger beneath $B$. tectorum than perennial grasses, supporting our hypothesis that $B$. tectorum senescence increased available $\mathrm{N}$ pools, and thus likely increased $\mathrm{N}$ availability, by reducing plant uptake and releasing all biomass N. Most B. tectorum studies have also found more inorganic $\mathrm{N}$ beneath post-senescent $B$. tectorum than beneath perennial communities (Bolton et al. 1993, Booth et al. 2003b, Saetre and Stark 2005; but see Norton et al. 2008 who found more nitrate and faster $\mathrm{N}$ cycling, but less ammonium, beneath $B$. tectorum than perennial grasses).

Much less information exists regarding the effects of B. tectorum invasion on pools of microbial biomass, DOC, and DON, although Bolton et al. (1993) found larger winter pools of microbial biomass beneath $B$. tectorum than perennial grasses - a period of time not covered in our study. Norton et al. (2008) found less DOC and DON beneath B. tectorum than perennial grasses in August, results that contrast somewhat with our findings that $B$. tectorum invasion increased DON across the growing season, but only increased DOC beneath $B$. tectorum versus perennial grasses in June and July (DOC was similar beneath both communities in August).

Although our analysis did not control for all of the important drivers of microbial processes (e.g., soil temperature), our results suggest strong roles for plant life span, phenology, and water in controlling soil pools of $\mathrm{C}$ and $\mathrm{N}$. Changes in life span, or the lack of inter-annual nutrient storage in annual communities, likely resulted in the larger soil pools of labile $\mathrm{C}$ and $\mathrm{N}$ we observed beneath annual versus perennial communities. Labile $\mathrm{C}$ and $\mathrm{N}$ pools appeared most influenced by phenological patterns of plant uptake and litter deposition, while microbial pools were strongly affected by soil water content.

Our results suggest that replacing perennial grass communities with $B$. tectorum could have important effects on nutrient dynamics and community composition. Inorganic $\mathrm{N}$ was higher under $B$. tectorum than native plants, especially after senescence. As inorganic $\mathrm{N}$ levels increase, B. tectorum becomes a better competitor against native species such as Bouteloua gracilis (Lowe et al. 2003) and elevated mineral $\mathrm{N}$ has been found to increase the success of B. tectorum if other resources are not limiting (Paschke et al. 2000, Adair et al. 2008). In this way, B. tectorum could facilitate its own spread and domination of plant communities. Alternatively, high inorganic $\mathrm{N}$ levels beneath stands of senesced B. tectorum, combined with $B$. tectorum induced increases in $\mathrm{N}$ cycling (e.g., Norton et al. 2008), could result in increased $\mathrm{N}$ losses through gaseous losses (Peterjohn and Schlesinger 1990, Davidson et al. 1993, Hungate 
et al. 1997, Norton et al. 2008) or leaching and erosion during large, intense late season rainfall events (Loik et al. 2004, Welter et al. 2005). Although relatively large $(>15 \mathrm{~mm})$, late-season events are common in this ecosystem $\left(1-2 \mathrm{mo}^{-1} \mathrm{yr}^{-1}\right.$; NCDC 2005), climate change-predicted increases in the occurrence of large, intense precipitation events (Gordon et al. 1992, Easterling et al. 2000, IPCC 2001) could exacerbate losses of labile $\mathrm{N}$ in $B$. tectorum dominated communities.

Acknowledgements Sonia Hall, John Bradford, and Drew Ditter provided invaluable assistance with lab and field work. Elizabeth Wolkovich and anonymous reviewers provided extremely helpful comments and critiques. Many thanks to Horsetooth Mountain Park and Larimer County Parks for allowing us to use park land for site locations and to the McIntyre-Stennis Program for funding.

Open Access This article is distributed under the terms of the Creative Commons Attribution Noncommercial License which permits any noncommercial use, distribution, and reproduction in any medium, provided the original author(s) and source are credited.

\section{References}

Adair EC (2005) Causes and Consequences of Exotic Species Invasion in the Ponderosa Pine Forests of Colorado's Front Range. PhD Dissertation Colorado State University, Fort Collins, Colorado.

Adair EC, Burke IC, Lauenroth WK (2008) Contrasting effects of resource availability and plant mortality on plant community invasion by Bromus tectorum L. Plant Soil 304:103-115

Austin AT, Vivanco L (2006) Plant litter decomposition in a semi-arid ecosystem controlled by photodegradation. Nature 442:555-558

Austin AT, Yahdjian L, Stark JM, Belnap J, Porporato A, Norton U, Ravetta DA, Schaeffer SM (2004) Water pulses and biogeochemical cycles in arid and semiarid ecosystems. Oecologia 141:221-235

Beck T, Joergensen RG, Kandeler E, Makeschin F, Nuss E, Oberholzer HR, Scheu S (1997) An inter-laboratory comparison of ten different ways of measuring soil microbial biomass C. Soil Biol Biochem 29:1023-1032

Belnap J, Phillips SL (2001) Soil biota in an ungrazed grassland: Response to annual grass (Bromus tectorum) invasion. Ecol Appl 11:1261-1275

Belnap J, Phillips SL, Sherrod SK, Moldenke A (2005) Soil biota can change after exotic plant invasion: does this affect ecosystem processes? Ecology 86:3007-3017

Belnap J, Phillips SL, Troxler T (2006) Soil lichen and moss cover and species richness can be highly dynamic: The effects of invasion by the annual exotic grass Bromus tectorum, precipitation, and temperature on biological soil crusts in SE Utah. Applied Soil Ecology 32:63-76
Bolton H, Smith JL, Link SO (1993) Soil microbial biomass and activity of a disturbed and undisturbed shrub-steppe ecosystem. Soil Biol Biochem 25:545-552

Bolton H, Smith JL, Wildung RE (1990) Nitrogen mineralization potentials of shrub-steppe soils with different disturbance histories. Soil Sci Soc Am J 54:887-891

Booth MS, Caldwell MM, Stark JM (2003a) Overlapping resource use in three Great Basin species: implications for community invasibility and vegetation dynamics. J Ecol 91:36-48

Booth MS, Stark JM, Caldwell MM (2003b) Inorganic N turnover and availability in annual-and perennialdominated soils in a northern Utah shrub-steppe ecosystem. Biogeochemistry 66:311-330

Bossuyt H, Denef K, Six J, Frey SD, Merckx R, Paustian K (2001) Influence of microbial populations and residue quality on aggregate stability. Applied Soil Ecology 16:195-208

Bottner P (1985) Response of microbial biomass to alternate moist and dry conditions in a soil incubated with C-14labeled and N-15-labelled plant material. Soil Biol Biochem 17:329-337

Brandt LA, King JY, Milchunas DG (2007) Effects of ultraviolet radiation on litter decomposition depend on precipitation and litter chemistry in a shortgrass steppe ecosystem. Global Change Biol 13:2193-2205

Brookes PC, Kragt JF, Powlson DS, Jenkinson DS (1985) Chloroform fumigation and the release of soil nitrogenthe effects of fumigation time and temperature. Soil Biol Biochem 17:831-835

Brown CS, Rowe HI (2007) The unwelcome arrival of Bromus tectorum to high elevations. In Proceedings of the High Altitude Revegatation Workshop, March 3-4, 2004, Fort Collins, CO

Burnham KP, Anderson DR (2002) Model Selection and Multimodel Inference: A Practical Information-Theoretic Approach. Springer-Verlag, New York

Clark FE, Woodmansee RG (1992) Nutrient Cycling. Ecosystems of the World 8A: Natural Grasslands. Elsevier, New York

Cleveland CC, Neff JC, Townsend AR, Hood E (2004) Composition, dynamics, and fate of leached dissolved organic matter in terrestrial ecosystems: Results from a decomposition experiment. Ecosystems 7:275-285

Collins SL, Sinsabaugh RL, Crenshaw C, Green L, PorrasAlfaro A, Stursova M, Zeglin LH (2008) Pulse dynamics and microbial processes in aridland ecosystems. J Ecol 96:413-420

Colorado Natural Heritage Program, CHNP (1999) Management Alternatives for Natural Communities and Imperiled Butterflies at Horsetooth Mountain Park, Larimer County, Colorado. http://www.cnhp.colostate.edu/download/documents/ 1999/Horsetooth Mountain Park Plan.pdf

Cui MY, Caldwell MM (1997) A large ephemeral release of nitrogen upon wetting of dry soil and corresponding root responses in the field. Plant Soil 191:291-299

Davidson EA, Matson PA, Vitousek PM, Riley R, Dunkin K, Garciamendez G, Maass JM (1993) Processes regulating soil emissions of $\mathrm{NO}$ and $\mathrm{N} 2 \mathrm{O}$ in a seasonally dry tropical forest. Ecology 74:130-139

Easterling DR, Meehl GA, Parmesan C, Changnon SA, Karl TR, Mearns LO (2000) Climate extremes: Observations, modeling, and impacts. Science 289:2068-2074 
Edmonds JE (2004) Dissolved Organic Carbon Dynamics in Urban and Desert Stream ecosystems. Dissertation. Arizona State University

Evans RD, Rimer R, Sperry L, Belnap J (2001) Exotic plant invasion alters nitrogen dynamics in an arid grassland. Ecol Appl 11:1301-1310

Fenn ME, Haeuber R, Tonnesen GS, Baron JS, GrossmanClarke S, Hope D, Jaffe DA, Copeland S, Geiser L, Rueth HM, Sickman JO (2003) Nitrogen emissions, deposition, and monitoring in the western United States. Bioscience 53:391-403

Fierer N, Schimel JP (2003) A proposed mechanism for the pulse in carbon dioxide production commonly observed following the rapid rewetting of a dry soil. Soil Sci Soc Am J 67:798-805

Fisher FM, Parker LW, Anderson JP, Whitford WG (1987) Nitrogen mineralization in a desert soil-Interacting effects of soil moisture and nitrogen fertilizer. Soil Sci Soc Am J 51:1033-1041

Ford DJ, Cookson WR, Adams MA, Grierson PF (2007) Role of soil drying in nitrogen mineralization and microbial community function in semi-arid grasslands of north-west Australia. Soil Biol Biochem 39:1557-1569

Gordon HB, Whetton PH, Pittock AB, Fowler AM, Haylock MR (1992) Simulated changes in daily rainfall intensity due to the enhanced greenhouse-effect-Implications for extreme rainfall events. Climate Dynamics 8:83-102

Halverson LJ, Jones TM, Firestone MK (2000) Release of intracellular solutes by four soil bacteria exposed to dilution stress. Soil Sci Soc Am J 64:1630-1637

Harris GA (1967) Some competitive relationships between Agropyron spicatum and Bromus tectorum. Ecol. Monogr. 37, 89-\&.

Harrison KA, Bol R, Bardgett RD (2008) Do plant species with different growth strategies vary in their ability to compete with soil microbes for chemical forms of nitrogen? Soil Biol. Biochem 40:228-237

Hart SC, Firestone MK, Paul EA, Smith JL (1993) Flow and fate of soil nitrogen in an annual grassland and a young mixed-conifer forest. Soil Biol Biochem 25:431-442

Hodge A, Stewart J, Robinson D, Griffiths BS, Fitter AH (1999) Plant, soil fauna and microbial responses to N-rich organic patches of contrasting temporal availability. Soil Biol Biochem 31:1517-1530

Hooker T, Stark J, Norton U, Leffler AJ, Peek M, Ryel R (2008). Distribution of ecosystem $\mathrm{C}$ and $\mathrm{N}$ within contrasting vegetation types in a semiarid rangeland in the Great Basin, USA. Biogeochemistry 90:291-308

Hulbert LC (1955) Ecological Studies of Bromus tectorum and Other Annual Bromegrasses. Ecol Monogr 25:181213

Hungate BA, Lund CP, Pearson HL, Chapin FS (1997) Elevated $\mathrm{CO} 2$ and nutrient addition alter soil $\mathrm{N}$ cycling and $\mathrm{N}$ trace gas fluxes with early season wet-up in a California annual grassland. Biogeochemistry 37:89-109

Huxman TE, Snyder KA, Tissue D, Leffler AJ, Ogle K, Pockman WT, Sandquist DR, Potts DL, Schwinning S (2004) Precipitation pulses and carbon fluxes in semiarid and arid ecosystems. Oecologia 141:254-268

Intergovernmental Panel on Climate Change, IPCC (2001) Climate Change 2001: Synthesis Report, Third Assess- ment Report of the Intergovernmental Panel on Climate Change. Cambridge University Press, New York

Jackson LE, Strauss RB, Firestone MK, Bartolome JW (1988) Plant and soil nitrogen dynamics in California annual grassland. Plant Soil 110:9-17

James JJ, Aanderud ZT, Richards JH (2006) Seasonal timing of $\mathrm{N}$ pulses influences $\mathrm{N}$ capture in a saltbush scrub community. J Arid Environ 67:688-700

Jones DL, Shannon D, Junvee-Fortune T, Farrar JF (2005) Plant capture of free amino acids is maximized under high soil amino acid concentrations. Soil Biol Biochem 37:179-181

Jones DL, Shannon D, Murphy DV, Farrar J (2004) Role of dissolved organic nitrogen (DON) in soil $\mathrm{N}$ cycling in grassland soils. Soil Biol Biochem 36:749-756

Jones DL, Willett VB (2006) Experimental evaluation of methods to quantify dissolved organic nitrogen (DON) and dissolved organic carbon (DOC) in soil. Soil Biol and Biochem 38:991-999

Killham K (1994) Soil Ecology. Cambridge University Press, Cambridge

Kremer RG, Running SW (1996) Simulating seasonal soil water balance in contrasting semi-arid vegetation communities. Ecol Model 84:151-162

Larimer County Parks, Open Lands, LCPOL (2006) Horsetooth Mountain Park, Resource Conservation and Visitor Experience Management Plan. http://www.co.larimer.co.us/ parks/htmp.htm

Loik ME, Breshears DD, Lauenroth WK, Belnap J (2004) A multi-scale perspective of water pulses in dryland ecosystems: climatology and ecohydrology of the western USA. Oecologia 141:269-281

Lowe PN, Lauenroth WK, Burke IC (2003) Effects of nitrogen availability on competition between Bromus tectorum and Bouteloua gracilis. Plant Ecol 167:247-254

Lundquist EJ, Jackson LE, Scow KM (1999) Wet-dry cycles affect dissolved organic carbon in two California agricultural soils. Soil Biol Biochem 31:1031-1038

Mack RN (1981) Invasion of Bromus tectorum L into western North America - an ecological chronicle. Agro-Ecosystems $7: 145-165$

Mack RN (1986) Alien plant invasion into the Intermountain West: a case history In Ecology of Biological Invasions of North America and Hawaii. Ecological Studies 58: 191-213 Eds. H A Mooney and J A Drake. Springer-Verlag, New York.

Miller ME, Belnap J, Beatty SW, Webb BL (2006) Effects of water additions, chemical amendments, and plants on in situ measures of nutrient bioavailability in calcareous soils of southeastern Utah, USA. Plant Soil 288:19-29

National Climatic Data Center NCDC (2005) Daily surface data for 1900-2003 from: Buckhorn Mountain 1e, Larimer County, Colorado, Station ID 051060; Fort Collins 4e, Larimer County, Colorado, Station ID 53006; Fort Collins, Larimer County, Colorado, Station ID 53005; Loveland NCWCD, Larimer County, Colorado, Station ID 55236; Flatiron 8 WSW, Larimer County, Colorado Station ID 52934, Virginia Dale 7 ENE, Larimer County, Colorado, Station ID 58690; Waterdale, Larimer County, Colorado, Station ID 58839; Wellington 5 WNW. Larimer County, Colorado, 58907

Norton U, Mosier AR, Morgan JA, Derner JD, Ingram LJ, Stahl PD (2008). Moisture pulses, trace gas emissions and soil C 
and $\mathrm{N}$ in cheatgrass and native grass-dominated sagebrushsteppe in Wyoming, USA. Soil Biology \& Biochemistry 40:1421-1431

Noy-Meir I (1973). Desert ecosystems: environment and producers. Annual Review of Ecology and Systematics 4:25-52

Nye PH, Tinker PB (1977) Solute Movement in the Soil-Root System. Blackwell, Oxford, p 342

Ogle SM, Reiners WA (2003) Impacts of exotic annual brome grasses (Bromus spp.) on ecosystem properties of northern mixed grass prairie. Am Midl Nat 149:46-58

Paschke MW, McLendon T, Redente EF (2000) Nitrogen availability and old-field succession in a shortgrass steppe. Ecosystems 3:144-158

Peterjohn WT, Schlesinger WH (1990) Nitrogen loss from deserts in the southwestern United States. Biogeochemistry 10:67-79

Rickard WH (1985a) Biomass and shoot production in an undisturbed sagebrush bunchgrass community. Northwest Sci 59:126-133

Rickard WH (1985b) Shoot production and mineral nutrient assimilation in cheatgrass communities. Northwest Sci 59:169-179

Rimer RL, Evans RD (2006) Invasion of downy brome (Bromus tectorum L.) causes rapid changes in the nitrogen cycle. Am Midl Nat 156:252-258

Saetre P, Stark JM (2005) Microbial dynamics and carbon and nitrogen cycling following re-wetting of soils beneath two semi-arid plant species. Oecologia 142:247-260

Sala OE, Lauenroth WK (1982) Small rainfall events-an ecological role in semi-arid regions. Oecologia 53:301304
Schwinning S, Sala OE (2004) Hierarchy of responses to resource pulses in and and semi-arid ecosystems. Oecologia 141:211-220

Singh JS, Lauenroth WK, Heitschmidt RK, Dodd JL (1983) Structural and functional attributes of the vegetation of northern mixed prairie of North America. Bot Rev 49:117-149

Sparks DL (1996) Methods of Soil Analysis Part 3: Chemical Methods. Soil Science Society of America and American society of Agronomy, Madison

Sperry LJ, Belnap J, Evans RD (2006) Bromus tectorum invasion alters nitrogen dynamics in an undisturbed arid grassland ecosystem. Ecology 87:603-615

Sterner RW, Elser JJ (2002) Ecological Stoichiometry: the Biology of Elements from Molecules to the Biosphere. Princeton University Press, Princeton, p 439

Svejcar T, Sheley R (2001) Nitrogen dynamics in perennial-and annual-dominated arid rangeland. J Arid Environ 47:33-46

Wedin DA, Tilman D (1990) Species effects on nitrogen cycling - a test with perennial grasses. Oecologia 84:433-441

Welter JR, Fisher SG, Grimm NB (2005) Nitrogen transport and retention in an arid land watershed: Influence of storm characteristics on terrestrial-aquatic linkages. Biogeochemistry 76:421-440

Woodmansee RG, Duncan DA (1980) Nitrogen and phosphorus dynamics and budgets in annual grasslands. Ecology 61:893-904

Zak DR, Holmes WE, MacDonald NW, Pregitzer KS (1999) Soil temperature, matric potential, and the kinetics of microbial respiration and nitrogen mineralization. Soil Sci Soc Am J 63:575-584 